\title{
Vaginal pessaries in urinary incontinence: integrative review
}

\section{Pessários vaginais na incontinência urinária: revisão integrativa}

\section{Pesarios vaginales em la incontinência urinaria: revisión integrada}

Priscilla Daun de Assis de Oliveira*, Carolina Bueno Somense, Natalia Aparecida de Barros, Eliana de Fatima Martins Greghi, Neusa Maria Costa Alexandre, Sonia Regina Pérez Evangelista Dantas, Néria Invernizzi da Silveira

ORCID IDS

Oliveira PDA (iD https://orcid.org/0000-0002-7067-6335

Somense CB (D) https://orcid.org/0000-0002-2507-1791

Barros NA (D. https://orcid.org/0000-0002-3683-925X

Greghi EFM (D) https://orcid.org/0000-0002-8716-4918

Alexandre NMC (D) https://orcid.org/0000-0001-5005-3360

Dantas SRPE D https://orcid.org/0000-0002-9639-8900

Silveira NI (iD https://orcid.org/0000-0003-1677-4206

\section{HOW TO CITE}

Oliveira PDA, Somense CB, Barros NA, Greghi EFM, Alexandre NMC, Dantas SRPE, Silveira NI. Vaginal pessaries in urinary incontinence: integrative review. ESTIMA, Braz. J. Enterostomal Ther., 16: e0419. https://doi.org/10.30886/estima.v16.661 IN

\begin{abstract}
Objectives: To analyze the types of pessaries, indications and impact in the treatment of urinary incontinence (UI). Methods: This is an integrative review with publications from 2007 to 2017 indexed in the Biblioteca Virtual em Saúde, Medical Literature Analysis and Retrieval System Online databases, Scopus Info Site, Cumulative Index to Nursing and Allied Health Literature and Web of Science. Results: Eight articles were selected. The pessaries indicated were the dish, ring, Uresta ${ }^{\circledR}$, and Contiform ${ }^{\circ}$. The reduction or resolution of stress UI in women was observed by analysis of objective parameters such as urodynamic evaluation and quality of life questionnaires. Economic viability was highlighted. Disability, difficulties in use, discomfort, and maintenance of urinary losses were evidenced among the reasons for non-adherence. Advanced prolapse and short vaginal length were predictive of failure. Adverse events were identified in low incidence: urinary retention and leukorrhea. Conclusion: Pessary therapy is effective in the treatment of SUI when accompanied by trained professionals. Individual characteristics and perceptions about the device are determinants of therapeutic success. Studies of greater sampling, follow-up time and quality, as well as stimulation to national publications, are necessary for the investigation of objective measures of $\mathrm{UI}$, clinical and demographic factors in relation to the success of the pessary.
\end{abstract}

DESCRIPTORS: Urinary incontinence; Pessaries; Nursing; Stomatherapy.

1.Universidade Estadual de Campinas - Faculdade de Enfermagem - Campinas/SP - Brazil

*Correspondence author: pridaun@gmail.com

Received: Oct. 292018 | Accepted: Mar. 282019 


\section{RESUMO}

Objetivo: Analisar os tipos de pessários, as indicações e o impacto no tratamento da incontinência urinária (IU). Métodos: Trata-se de revisão integrativa com publicações de 2007 a 2017 indexadas nas bases de dados Biblioteca Virtual em Saúde, Medical Literature Analysis and Retrieval System Online, Scopus Info Site, Cumulative Index to Nursing and Allied Health Literature e Web of Science. Resultados: Selecionaram-se oito artigos. Os pessários indicados foram prato, anel, Uresta® e Contiform®. A redução ou resolução da IU de esforço (IUE) em mulheres foi observada por análise de parâmetros objetivos, como avaliação urodinâmica e questionários de qualidade de vida. Destacou-se viabilidade econômica. Evidenciaram-se desajuste, dificuldades no uso, incômodo e manutenção de perdas urinárias entre os motivos de não adesão. Prolapso avançado e comprimento vaginal curto foram preditivos de insucesso. Identificaram-se eventos adversos em baixa incidência: retenção urinária e leucorreia. Conclusão: A terapia pessária é eficaz no tratamento da IUE quando acompanhada por profissionais capacitados. Características individuais e percepções sobre o dispositivo são determinantes no sucesso terapêutico. Estudos de maior amostragem, tempo de seguimento e qualidade, bem como estimulo a publicações nacionais, são necessários para investigação de medidas objetivas de IU, fatores clínicos e demográficos em relação ao sucesso do pessário.

DESCRITORES: Incontinência Urinária; Pessários; Enfermagem; Estomaterapia.

\section{RESUMEN}

Objetivo: Analisar los tipos de pesarios, indicaciones e impacto en el tratamiento de la Incontinencia Urinaria (IU). Método: Se trata de una revisión integrada com publicaciones de 2007 a 2017 organizado en la base de datos: La Biblioteca Virtual en Salud; Medical Literature Analysis and Retrieval System Online; Scopus Info Site; Cummulative Index to Nursing and Allied Health Literature; Web of Science. Resultados: Se seleccionaron ocho artículos. Los pesarios indicados fueron plato, anillo, Uresta® y Contiform ${ }^{\circledR}$. La reducción o resolución de las pérdidas urinarias em mujeres com IU de esfuerzo fueram obserradas por análisis de parámetros objetivos, como el estudio urodinámico y cuestionarios de calidad de vida. Se destacó la viabilidad económica. Se evidenció desajuste, dificultades en el uso, incómodo y manutención de pérdidas urinarias entre los motivos de no adhesión. Prolapso de orgasos pélvicos avanzado y tamaño vaginal curto fueran predictivos de fracaso. Se identificaran eventos adversos en baja incidencia: retención urinaria y fujo vaginal. Conclusión: La terapia com pesarios es eficaz en el tratamiento de la IU de esfuerzo cuando esta acompañada por profesionales capacitados. Caracteristicas individuales y percepciones sobre el dispositivo son determinantes en el exito de la terapia. Estudios de mayor muestreo, tiempo de seguimiento y calidad, bien como el estímulo a las publicaciones nacionales son necesarios para la investigación de medidas objetivas de IU, factores clínicos y demográficos en relación al exito de los pesarios.

DESCRIPTORES: Incontinencia Urinaria; Pesarios; Enfermería; Estomaterapia.

\section{INTRODUCTION}

By 2018, an estimated 120 million men and 301 million women are suffering from urinary incontinence (UI), involuntary loss of urine ${ }^{1,2}$. In the United States, in 2000, US\$14.2 billion, about US\$801 per non-institutionalized person, was spent on UI treatment, with US\$ 553 million in productivity burdens ${ }^{3}$. In women, a prevalent population, stress UI predominates, associated with physical activity, sneezing or coughing, and mixed (MUI), urgency and stress ${ }^{1}$. The literature indicates impairment of quality of life (QoL); a Brazilian study identified a serious impairment in daily living activities in $63.9 \%$ of women suffering from SUI ${ }^{4}$ and U.S. study linked UI to increased risk for depression and disability ${ }^{5}$.

Pessaries, minimally invasive intravaginal devices, are described as a UI treatment option for women of any age group, especially those who wish to avoid or have contraindications to surgical treatment ${ }^{1,6-8}$. Among other advantages, they have a relatively low cost and risk, provide immediate relief of symptoms, and the possibility of being used in addition to other conservative therapies, such as exercises of the pelvic floor musculature ${ }^{1,6-8}$. The earliest reports of pessaries date back to Ancient Egypt associated with pelvic organ prolapse (POP) treatment ${ }^{9}$, an indication that remains up to date ${ }^{1,6}$. In evolution, there are reports of half pomegranate soaked in vinegar (350 BC), stringwrapped sponges wrapped in wax and covered with oil or butter (1559 AD), up to current silicone models9.

Despite the advantages observed in the clinical treatment of UI by means of pessaries, they are suspected to be underutilized. This question is justified by the current panorama of underreporting and neglect in the care of people with IU allied to the incipient theoretical and practical training of health professionals about this clinical condition, often restricted to postgraduate courses, and lack of randomized 
controlled studies that support clinical practice, based today mainly on the opinion of experts, occasionally conflicting ${ }^{1,10,11 .}$ In this context, this review study aims to analyze the types of pessaries, indications and the impact on the treatment of UI in order to provide subsidies for this clinical practice.

\section{METHODS}

The integrative review was used as a method of searching and summarizing the evidence for its ability to gather and synthesize relevant information from studies with different methodological designs, providing a critical and comprehensive assessment of the subject in order to support clinical practice based on evidence and point out gaps ${ }^{12}$.

This review was developed and described in six methodological steps, according to Mendes et al. ${ }^{12}$. In the first step, the following guiding question was elaborated: what is the evidence about the use of vaginal pessaries in the treatment of UI?

In the second step, represented as a flowchart (Fig. 1), the databases to be studied, the search or sampling strategies, and the inclusion and exclusion criteria of studies were determined. The literature review was carried out at the index databases Biblioteca Virtual em Saúde (BVS), Medical Literature Analysis and Retrieval System Online (MEDLINE), Scopus Info Site (Scopus), Cumulative Index to Nursing and Allied Health Literature (CINAHL) and Web of Science. Different search strategies with the controlled descriptors (MeSH/DeCS), article indexing tools and search facilitators were used: Incontinência Urinária/Urinary Incontinence/Incontinencia Urinaria, Pessários/Pessaries/ Pesarios, and their synonyms, uncontrolled descriptors:
Incontinence, Urinary, and Pessary. Among the controlled descriptors, we used the Boolean operator AND and, among the uncontrolled descriptors, OR.

Intervention/experimental studies (randomized, nonrandomized clinical trials and community intervention studies), cohort, case-control and systematic review published from 2007 to 2017 in national and international journals in the English, Spanish and Portuguese languages were included in the sample, consistent with the objectives and guiding question of this study. Repeated or no full-text articles were excluded. The articles were independently peer-reviewed.

The third step consisted in the categorization of the sample with the following information extracted from the selected studies: reference, type of study, subjects, type of incontinence, type of pessary, time of follow-up of therapy, reasons for failure, adverse events, conclusions and limitations of the study. In the fourth step, from the analysis of this database, the evaluation of the sample that originated the results was developed. In the fifth stage, the discussion or interpretation of the results was carried out. Finally, in the sixth stage, were constructed the synthesis document and the presentation of this revision.

\section{RESULTS}

Eight articles were selected, according to the flowchart shown in Fig. 1. Despite the selection of 46 articles for reading in full, $38 \mathrm{had}$ as main theme the application of pessaries for treatment of pelvic organ prolapse and were excluded.

Tables 1 and 2 present the characteristics and relevant data selected by the reviewers for this study.

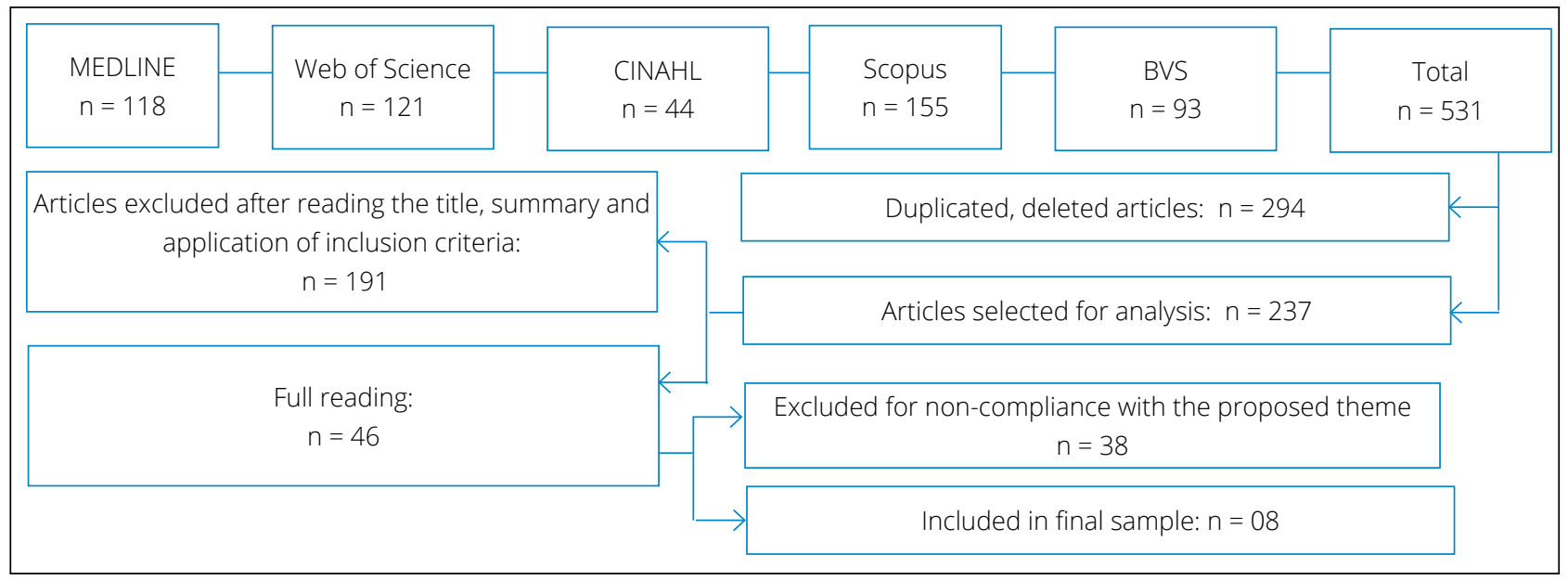

Figure 1. Flowchart of the selection process of the articles according to the databases. Campinas/São Paulo, Brazil. 
Table 1. Distribution of selected studies according to the article number, title, author, year, period, type of study, subjects, type of incontinence, type of pessary and follow-up time. Campinas/State of São Paulo, 2018.

\begin{tabular}{|c|c|c|c|c|c|}
\hline $\begin{array}{l}\text { Number of } \\
\text { the article }\end{array}$ & Title & $\begin{array}{c}\text { Author (year)/ } \\
\text { Journal }\end{array}$ & Type of study & $\begin{array}{l}\text { Subject*/Type of } \\
\text { incontinence }\end{array}$ & $\begin{array}{l}\text { Type of pessary/ } \\
\text { Follow-up time }\end{array}$ \\
\hline 1 & $\begin{array}{l}\text { Effectiveness of a } \\
\text { new self-positioning } \\
\text { pessary for the } \\
\text { management of } \\
\text { urinary incontinence } \\
\text { in women }\end{array}$ & $\begin{array}{l}\text { Farrell et al. (2007)/ } \\
\text { Am J Obstet Gynecol }\end{array}$ & Longitudinal & $32 / S U I$ or MUI & Uresta $® / 12$ months \\
\hline 2 & $\begin{array}{l}\text { Effects of the } \\
\text { incontinence } \\
\text { dish pessary on } \\
\text { urethral support } \\
\text { and urodynamic } \\
\text { parameters }\end{array}$ & $\begin{array}{l}\text { Noblett et al. (2008)/ } \\
\text { Am J Obstet Gynecol }\end{array}$ & Longitudinal & 33/SUI & $\begin{array}{l}\text { Dish/during } \\
\text { urodynamic } \\
\text { evaluation }\end{array}$ \\
\hline 3 & $\begin{array}{l}\text { Restoration of } \\
\text { continence by } \\
\text { pessaries: magnetic } \\
\text { resonance imaging } \\
\text { assessment of } \\
\text { mechanism of action }\end{array}$ & $\begin{array}{l}\text { Komesu et al. (2008)/ } \\
\text { Am J Obstet Gynecol }\end{array}$ & Almost experimental & 15/SUI & $\begin{array}{c}\text { Dish/during } \\
\text { urodynamic } \\
\text { evaluation and } \\
\text { resonance imaging }\end{array}$ \\
\hline 4 & $\begin{array}{l}\text { Update: the } \\
\text { "Contiform" } \\
\text { intravaginal device } \\
\text { in four sizes for the } \\
\text { treatment of stress } \\
\text { incontinence }\end{array}$ & $\begin{array}{c}\text { Allen et al. (2008)/Int } \\
\text { Urogynecol J }\end{array}$ & Longitudinal & 37/SUI and MUI & $\begin{array}{l}\text { Contiform } \AA / \\
4 \text { weeks }\end{array}$ \\
\hline 5 & $\begin{array}{l}\text { Incontinence } \\
\text { pessaries: size, } \\
\text { POPQ measures, and } \\
\text { successful fitting }\end{array}$ & $\begin{array}{l}\text { Nager et al. (2009)/ } \\
\text { Int Urogynecol J }\end{array}$ & Intervention & 266/SUI & $\begin{array}{l}\text { Dish or ring/ } \\
\text { not specified }\end{array}$ \\
\hline 6 & $\begin{array}{l}\text { A trial of continence } \\
\text { pessary vs. } \\
\text { behavioral therapy } \\
\text { vs. combined } \\
\text { therapy for stress } \\
\text { incontinence }\end{array}$ & $\begin{array}{l}\text { Richter et al. (2010)/ } \\
\text { Obstet Gynecol }\end{array}$ & Longitudinal & 446/SUI or MUI & $\begin{array}{l}\text { Dish or ring/ } \\
12 \text { months }\end{array}$ \\
\hline 7 & $\begin{array}{l}\text { Pelvic floor } \\
\text { symptoms } \\
\text { improve similarly } \\
\text { after pessary } \\
\text { and behavioral } \\
\text { treatment for stress } \\
\text { incontinence }\end{array}$ & $\begin{array}{l}\text { Kenton et al. (2012)/ } \\
\text { Female Pelvic Med } \\
\text { Reconstr Surg }\end{array}$ & Intervention & 295/SUI or MUI & $\begin{array}{l}\text { Dish or ring/ } \\
3 \text { months }\end{array}$ \\
\hline 8 & $\begin{array}{l}\text { Short-term Uresta } \\
\text { efficacy (SURE) } \\
\text { study: a randomized } \\
\text { controlled trial of the } \\
\text { Uresta continence } \\
\text { device }\end{array}$ & $\begin{array}{l}\text { Lovatsis et al. (2017)/ } \\
\text { Int Urogynecol J }\end{array}$ & Intervention & 36/ SUI or MUI & $\begin{array}{c}\text { Uresta } \AA / \text { during the } \\
\text { Pad test }\end{array}$ \\
\hline
\end{tabular}

*Women. SUI: Stress urinary incontinence; MUI: mixed urinary incontinence with a predominance of stress symptoms. 
Table 2. Distribution of articles regarding article number, results and conclusions, reasons for failure and adverse events, and study limitations. C

$\begin{array}{ccc}\mathrm{N} \text { of } & \text { Results and Conclusions } & \text { Reasons for failure/Adverse } \\ \text { the } & \text { events (AE) } & \text { Limitations of the } \\ \text { article } & & \text { study }\end{array}$

Uresta®significantly reduced urinary incontinence (UI);

Easy to use, with improved quality of life (QoL); Results demonstrated with objective measures: Pad test, Incontinence Impact Questionnaire (IIQ) and Urogenital Distress Inventory (UDI); Mechanism of action: mechanical support to the urethra; The need for larger, prospective, comparative studies with placebo effect control and analysis of interfering factors in the success of therapy.

Pessary in plate solved the majority of UI cases; Results demonstrated in the urodynamic evaluation and Q-tip test; Most of the women were satisfied; Mechanism of

2 action: enhancement of urethrovesical junction support an increase of maximum urethral closure pressure; Studies are needed to evaluate the bladder emptying function related to the risk of urinary retention.

Fall of the pessary, discomfort, disliked maintenance of urinary losses. Greater parity: predictive of difficulty in adjustment./AE: none.
Small number of participants; absence of control group. In magnetic resonance and urodynamic evaluation, the following mechanisms of continence of the pessary in

3 the plate were observed: reduction of the posterior urethrovesical angle, reduction and blunting of the bladder neck, increase in functional length and urethral resistance.

Maintenance of urinary losses, discomfort Advanced pelvic organ prolapse (POP): predictive of failure/EA: reduction of the mean flow rate by $2 \mathrm{~mL} / \mathrm{s}$.
Urodynamic evaluation does not faithfully mimic the conditions of real life.

In magnetic resonance and urodynamic evaluation, the
following mechanisms of continence of the pessary in
the plate were observed: reduction of the posterior
urethrovesical angle, reduction and blunting of the bladder
neck, increase in functional length and urethral resistance.

Contiform ${ }^{\circledR}$ significantly reduced Ul; Economically viable;

4 Results demonstrated with Pad test de 24 h, UDI, IIQ and St. George score (20-point index scale of incontinence).

The majority of women with effort UI without advanced

5 pelvic organ prolapse (POP) may succeed in pessary therapy if accompanied by trained professionals.

Pessary therapy is an alternative to behavioral therapy for patients who desire non-surgical management of SUI and are unable or resistant to pelvic floor muscle training 6 (PFMT). Combination therapy was not superior to single therapy. Results demonstrated with Global Impression of Improvement (PGI-I), Pelvic Floor Distress Inventory (PFDI) and Patient Satisfaction Question (PSQ). Studies are needed to investigate barriers to adherence to these treatments.

Behavioral and pessary treatment are equivalent and clinically effective and important in the treatment of SUI, the choice depends on individual characteristics and preferences. Results demonstrated by QOL questionnaires: PFDI, Pelvic Floor Impact Questionnaire (PFIQ), Urinary Incontinence Diagnosis (QUID). Need for studies investigating clinical factors associated with the success of conservative treatment.

Uresta ${ }^{\circledR}$ is effective in the treatment of SUI by reducing objective measures of UI evaluated by Pad test.
No record/AE: no record.

Insufficient sample for significant analysis.
Fall of the pessary, difficulty in removal.Small vaginal length or introitus and prior gynecologic surgery: predictors of failure/AE: urinary retention.

Unwillingness to use, mismatch,

pain. Small vaginal length: predictive of failure/AE: no record
Not pointed.

Results do not apply to women with advanced POP.
Unwillingness to use,

maladjustment, urinary losses/AE: Not pointed. leucorrhoea. 


\section{DISCUSSION}

For purposes of analysis and discussion of the identified articles, three categories were created: limitations of the literature, types of pessaries and indications for UI treatment and impact on treatment (positive and negative aspects).

\section{Category 1: Limitations of the literature}

The final sample of this review consisted of eight scientific articles selected by the inclusion and exclusion criteria previously established.

Regarding the origin of the studies, all were published in the English language and in international journals. As for the year of publication, the highlight was the year of 2008, with $37.5 \%$ of publications, followed by $12.5 \%$ in 2007,2009 , 2010, 2012 and 2017, observing a decrease in the number of publications. As for the methodological approach, it was found that $50 \%$ corresponded to longitudinal studies, $38 \%$ to intervention studies and $12.5 \%$ to almost experimental ones. Regarding the time of follow-up and evaluation of the therapy, $25 \%$ followed for 1 year, $12.5 \%$ for 3 months, $12.5 \%$ for 4 weeks, $37.5 \%$ during the exams and $12.5 \%$ did not specify.

According to the literature, the shortage of articles with a higher level of evidence related to the topic, coupled with the high prevalence of small-group studies $(62.5 \%$ of the studies involved up to 37 women) and limited follow-up time, demonstrated that pessary therapy is in the process of consolidation as science and discovery by patients and health professionals ${ }^{1,9,12.13}$, who are transposing sophisms of pessary inefficiency in the treatment of $\mathrm{UI}^{13,14}$. Thus, studies of greater sampling, follow-up time and quality, as well as a stimulus to national publications, absent in this study, are necessary, although the Brazilian scientific literature grows above the world average ${ }^{15}$.

\section{Category 2: Types of pessaries and indications for UI treatment}

Pessary is indicated in the literature as a non-surgical treatment option for $\mathrm{SUI}^{6,14}$. It was evidenced in this study that all the selected studies treated women with SUI and 62.5\% also with MUI, with a predominance of stress symptoms. In the treatment of these dysfunctions, the pessaries in ring, with button and holder, dish and Uresta were prescribed in other studies ${ }^{6}$,consistent with the data of this review, when the following indications were observed: pessary in dish $(62.5 \%)$, in ring $(37,5 \%)$ and three worked with specific devices, Uresta ${ }^{\circledR}(25 \%)$ and Contiform ${ }^{\circledR}(12.5 \%)$.

According to the literature ${ }^{1}$, in this study, pessary therapy was indicated as an alternative to the training of pelvic floor muscles (PFMT) for patients who desired non-surgical management of SUI and were incapable or resistant to PFMT. Both therapies were considered clinically equivalent and combined therapy was not superior to single therapy. PFMT is indicated as a first line conservative treatment regardless of age because the integrity of this musculature is very relevant in the mechanism of continence ${ }^{1}$.

\section{Category 3: Impacts on treatment (positive and negative aspects)}

As observed in the literature $8,14,16$, Positive aspects such as economic viability; ease of insertion, fitting and withdrawal; low incidence of complications; adverse effects and discomfort, therefore low risk, are present in this review and are associated with the successful treatment of UI with pessaries, as well as their adherence. All studies reported resolution or reduction of urinary loss, attesting to the efficacy of the therapy. Some demographic and clinical aspects are mentioned in the literature as positive data regarding therapeutic success: being elderly, being postmenopausal, presenting less parity and not being a smoker ${ }^{16}$.

In the present review, length $(<7 \mathrm{~cm})$ or small vaginal introitus, greater parity, advanced POP and previous gynecological surgeries were characterized as predictive of failure. In two studies, adverse events with low incidence were also identified: vaginal discharge and urinary retention. Other unsuccessful factors reported in the literature are a cognitive deficit, high body mass index (BMI), and mobility restrictions, such as those caused by rheumatoid arthritis ${ }^{17,18}$.

In this review, the following reasons for non-adherence were identified: mismatch (25\%); fall of the pessary (25\%); disliked or unwilling to use (37.5\%); difficulty of removal or insertion (12.5\%); maintenance of urinary losses (37.5\%); pain or discomfort (37.5\%). Consonant to the literature, these results and the lack of specialized support influence the treatment negatively ${ }^{1,14,16,18-20}$. With the trend towards 
decentralization of care to people with UI for primary care, in order to democratize access to treatment, specialist or trained nurses are indicated as the ideal professionals to promote this care in a holistic and person-centered way and their family, social and economic structure ${ }^{1,21}$. However, it is believed that the reasons related to nonadherence are much more complex and are related to the capacity of resources and structuring of the health system, knowledge of the patient, of the health professional and their perceptions regarding pessaries ${ }^{15,21,22}$.

It was observed in the present review that two articles demonstrated the efficacy of the pessaries through the urodynamic study, whose purpose is to investigate the functioning and dysfunctions of the urinary $\operatorname{tract}^{1}$. In this study, elementary mechanisms of pessary action were evidenced: stabilization, an increase of resistance and uretal functional length, as already exposed in the literature ${ }^{6,20}$. Among the main results, the reduction of the posterior urethrovesical angle was identified in the Q-tip test; in the urodynamic evaluation, the increase of the maximum urethral closure pressure. Other objective measures, in addition to urodynamic parameters such as Pad test and QOL and incontinence questionnaires, are prone to assess pessary therapy in order to make it scientific.

\section{CONCLUSION}

Data from the present study suggest that pessary therapy is effective in the control and treatment of SUI and MUI, with predominance of effort symptoms as long as they are accompanied by trainned professionals. However, the particular characteristics of each woman and their perceptions directly influence the success of the therapy, which is still in process of being consolidated as science and discovery by patients and health professionals. The structuring of the health system and the guarantee for resources that are fundamental for democratization of access to therapy. The number of publications of intervention, cohort and case control studies and systematic reviews is incipient. Major sample studies, follow-up time and quality, aswell as the encouragement to national publications are required for investigation of objective UI measures, clinical and demographic factors related to the success of pessary therapy.

\section{ACKNOWLEDGEMENTS}

We thank Ana Paula de Morais e Oliveira, librarian of the Faculdade de Ciências Médicas da UNICAMP, for the support and teaching, fundamental in the initial stages of our work.

\section{CONTRIBUTION OF AUTHORS}

Investigation, Barros NA de; Somense CB; Greghi EFM; Oliveira PDA; Writing - First version, PDA Oliveira; Somense CB; Greghi EFM; Barros NA de; Writing - Review \& Edition, Alexandre NMC; PDA Oliveira; Somense CB; Greghi EFM; Barros NA de; Dantas SRPE; Silveira NI da; Supervision, Alexandre NMC.

\section{REFERENCES}

1. Abrams P, Cardozo L, Wagg A, Wein A. Incontinence. 6a ed. Bristol: International Continence Society; 2017.

2. Irwin DE, Kopp ZS, Agatep B, Milsom I, Abrams P. Worldwide prevalence estimates of lower urinary tract symptoms, overactive bladder, urinary incontinence and bladder outlet obstruction. BJU Int. 2011;108(7):1132-8. https://doi. org/10.1111/j.1464-410X.2010.09993.x

3. Hu TW, Wagner TH, Bentkover JD, Leblanc K, Zhou SZ, Hunt T. Costs of urinary incontinence and overactive bladder in the United States: a comparative study. Urology. 2004;63(3):4615. https://doi.org/10.1016/j.urology.2003.10.037

4. Gomes GV, Silva GD. Incontinência urinária de esforço em mulheres pertencentes ao Programa de Saúde da Família de Dourados (MS). Rev Assoc Med Bras. 2010;56(6):649-54. https://doi.org/10.1590/S0104-42302010000600011
5. Hung KJ, Awtrey CS, Tsai AC. Urinary incontinence, depression, and economic outcomes in a cohort of women between the ages of 54 and 65 years. Obstet Gynecol. 2014;123(4):822-7. https://doi.org/10.1097/AOG.0000000000000186

6. Robert M, Schulz JA, Harvey MA, Lovatsis D, Walter JE; Urogynaecology Committee. Technical update on pessary use. J Obstet Gynaecol Can. 2013;35(7):664-74. https://doi. org/10.1016/S1701-2163(15)30888-4

7. Kobashi KC, Albo ME, Dmochowski RR, Ginsberg DA, Goldman HB, Gomelsky A, et al. Surgical treatment of female stress urinary incontinence: AUA/SUFU Guideline. J Urol. 2017;198(4):875-83. https://doi.org/10.1016/j. juro.2017.06.061

8. Von Bargen E, Patterson D. Cost utility of the treatment of stress urinary incontinence. Female Pelvic Med 
Reconstr Surg. 2015;21(3):150-3. https://doi.org/10.1097/ SPV.0000000000000159

9. Durfee RB. Management of genital organ prolapse. Foreword. Clin Obstet Gynecol. 1966;9(4):991-6.

10. Atnip $S, O^{\prime}$ Dell K. Vaginal support pessaries: indications for use and fitting strategies. Urol Nurs. 2012;32(3):114-24.

11. Locks MOH,Santos SMA. Uso de fralda geriátrica em hospitais: solução ou problema? ESTIMA, Braz J Enterostomal Ther. 2015;13(1):27-34. https://doi.org/10.5327/Z1806-31442015 $\underline{00010006}$

12. Mendes KDS, Silveira RCCP, Galvão CM. Revisão integrativa: método de pesquisa para a incorporação de evidências na saúde e na enfermagem. Texto contexto - enferm. 2008;17(4):758-64. https://doi.org/10.1590/50104-0707 2008000400018

13. Bugge C, Hagen S, Thakar R. Vaginal pessaries for pelvic organ prolapse and urinary incontinence: a multiprofessional survey of practice. Int Urogynecol J. 2013;24(6):1017-24. https://doi.org/10.1007/s00192-012-1985-7

14. Brown LK, Fenner DE, DeLancey JO, Schimpf MO. Defining patient knowledge and perceptions of vaginal pessaries for prolapse and incontinence. Female Pelvic Med Reconstr Surg. 2016;22(2):93-7. https://doi.org/10.1097/ SPV.0000000000000252

15. Barata G. Em revisão: o impacto da produção cientifica brasileira para o Brasil. Cienc Cult. 2015;67(4):6-8. https:// doi.org/ 10.21800/2317-66602015000400003

16. Lewthwaite BJ, Stakey D, Girouard L, Maslow K. Characteristics of women with continued use of vaginal pessaries. Urol
Nurs. 2013;33(4):171-6. https://doi.org/10.7257/1053-816X. 2013.33.4.171

17. Mclntosh L, Andersen E, Reekie M. Conservative treatment of stress urinary incontinence in women: a 10-year (2004-2013) scoping review of the literature. Urol Nurs. 2015;35(4):17986, 203. https://doi.org/10.7257/1053-816X.2015.35.4.179

18. Mao M, Ai F, Zhang Y, Kang J, Liang S, Xu T, et al. Predictors for unsuccessful pessary fitting in women with symptomatic pelvic organ prolapse: a prospective study. BJOG. 2018;125(11)1434-40. https://doi.org/10.1111/1471-0528. 15260

19. Ptak M, Brodowska A, Ciećwież S, Rotter I. Quality of life in women with stage 1 stress urinary incontinence after application of conservative treatment - A randomized trial. Int J Environ Res Public Health. 2017;14(6):E577. https://doi. org/10.3390/iierph14060577

20. Al-Shaikh G, Syed S, Osman S, Bogis A, Al-Badr A. Pessary use in stress urinary incontinence: a review of advantages, complications, patient satisfaction, and quality of life. Int J Womens Health. 2018;10:195-201. https://doi.org/10.2147/ IIWH.S152616

21. Hooper GL. Person-centered care for patients with pessaries. Nurs Clin N Am 2018;53(2):289-301. https://doi. org/10.1016/j.cnur.2018.01.006

22. Kammerer-Doak D, Svabik K, Bazi T. Variability in practice patterns in stress urinary incontinence and pelvic organ prolapse: results of an IUGA survey. Int Urogynecol J. 2017;28(5):735-44. https://doi.org/10.1007/s00192-0163174-6 